\title{
Actual Demographic Processes in the Republic of Tatarstan
}

\author{
Khusnutdinova S.R. ${ }^{\mathrm{a}}$ \\ Gaisin I.T.b \\ Biktimirov N.M.c \\ Gaisin R.I. ${ }^{d}$ \\ Safonova M.V.e \\ abcde Kazan Federal University, Institute of Management, Economics and Finance, Kazan, 420008, Russia
}

\section{Doi:10.5901/mjss.2015.v6n1s3p122}

\section{Abstract}

This article analyzes the current demographic characteristics of the Republic of Tatarstan. The key indicators of the demographic situation, such as the indicators of natural (birth and death rate) and migration of population have an uncertain future. Demographic indicators are influenced by a number of different factors which can be hard to predict. At the same time the demographic characteristics of the population have highly significant implications for economic and social development of any area in a long term perspective. Demographic characteristics and trends analysis is one of the most important points in understanding the demographic future of certain region and the country as a whole. Tatarstan is one of the most socioeconomically developed regions in Russia. In recent years birth rate exceeds its deaths rate in the republic and the urban population increases annually.

Keywords: demography, population, migration, city, population policy

\section{Introduction}

Demographic characteristics of the territory can be a decisive factor on its socio-economic development. The regional strategy over the next 15-20 years is required to take into account the current demographic characteristics of the territory and the prospects for their change. It is necessary for provide realistic scenarios for the development of the region and for the goals that is possible to achieve according existing and future demographic indicators. The demographic future is inherently uncertain that should be considered in socio-economic decisions, including marketing, financial and other $[1,2]$.

Such uncertainty exists due to factors such as an incomplete understanding of demographic processes, imperfect demographic data, and unpredictable immigration policy changes. Demographers solving this problem using functional data models for fertility, mortality and overseas migration $[1,3,4]$ For example, factors potential influencing people's choice for place to live and work during the pre-migration stage are not only socio-economic but psychoemotional (psychological well-being). It is difficult to obtain data on migrants in pre-migration stage [5].

Uncertainty in demographic future has a long-term effects and one of the most important steps in overcoming this uncertainty is a comprehensive analysis of the current demographic situation, the forces constraining or enabling certain demographic processes of society.

\section{Method}

For the study of demographic characteristics a number of methods were used. It is, in the first place, the statistical method, comparison method and spatio-temporal approach. Statistical data analysis and diagramming were obtained from the official web-site of Territorial authority of the Federal State Statistics Service of the Republic of Tatarstan http://tatstat.gks.ru/wps/wcm/connect/rosstat_ts/tatstat/ru/statistics/population/. 


\section{Main Part}

Tatarstan is one of the most economically developed regions in Russia. A population of 3.822 million people (2013) comprises 2 main ethnic groups - Tatars and Russians - their sum is more than 92 percent [6]

Tatarstan is highly urbanized, with $76 \%$ of the population living in urban areas. Both in absolute and in relative terms, the number of residents increase in recent years. It should be noted that high level of urbanization and migration is an important symbol of a regional economic development. For example, in the early 70's of the last century in Naberezhnye Chelny city Kamsky Motor Works (OJSC "KamAZ")- a manufacturer of heavy-duty vehicles were built. And as the result influx of migrants from different parts of Russia was increased significantly [7].Economic growth stimulates the migration - it occurs in many regions of the world. The impact of migration on economic (labor market) and social development (assimilation of migrants, inter-ethnic relations, the change in fertility) is significantly and diverse both in developed and developing countries. There are vast array of studies examining the migration impacts on economic and social development $[8,9,10,11]$.

Demographics and settlement system of the Republic of Tatarstan is influenced by phenomena and processes that are specific to the entire socio-economic situation of Russia. Decline in fertility and high mortality were observed in Russian Federation in the mid- 90's and were typical for republic too. In the late 90's republic's population increase has been due to migration. Increasing fertility is the result of active demographic policy at both the federal and regional level, as well as the stabilization of the economic situation in comparison with the 90's of the 20th century. An increase in fertility rates to $25 \%$ observed during the last 5 years (2008-2012). At the same time mortality stable and has a tendency to decrease. These phenomena were possible to overcome the negative trend of population decline and in 2011, the natural population decline has been replaced by natural growth, as shown in figure 1.

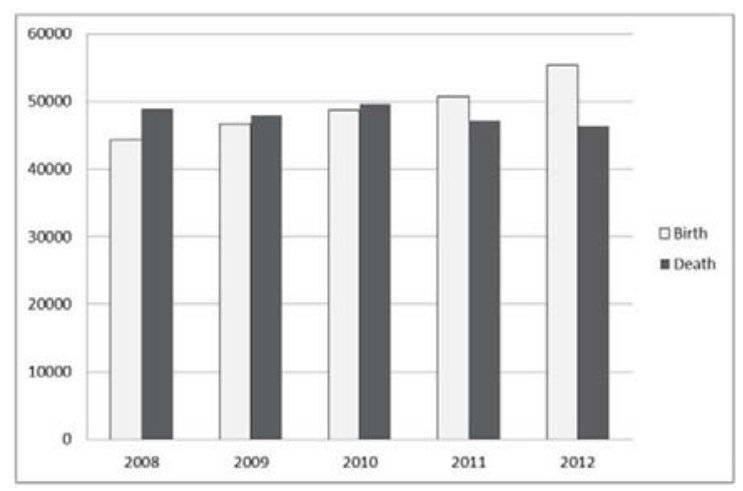

Figure 1. Dynamics of birth and death indicators in the Republic of Tatarstan in 2008-2012 periods (people)

Another important positive trend is the decline in the divorce rate during the growth of marriages, which may be indicative of the fact that family values strengthening in a society. In 2012, the divorce rate has decreased by 10 percent compared to 2008.A noteworthy fact is that the economic crisis of 2008 has had almost no a negative impact on (almost have not affected) marriage indicators.

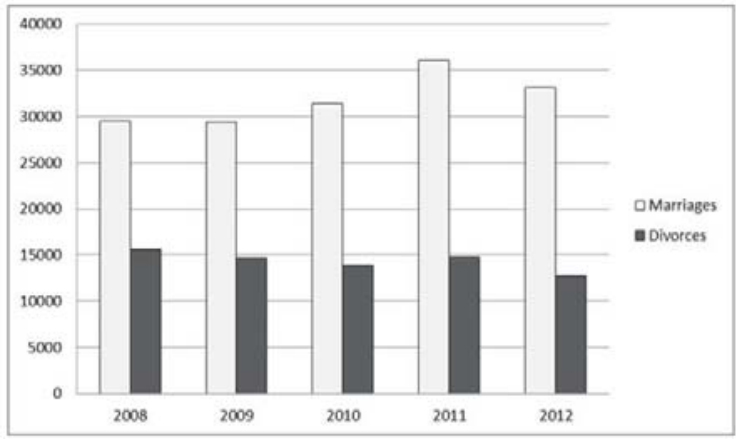

Figure 2. Dynamics of marriage and divorce indicators in the Republic of Tatarstan in 2008-2012. 
The rate of population growth during the last 5 years in the Republic of Tatarstan is mainly due to the positive migration balance. Data from the Table 3 clearly demonstrate (indicate) that the number of entrants exceeds the number of those who left the republic both in the general migration exchange and the internal migration in Russian Federation.

Table 3. Dynamics of migration growth in the Republic of Tatarstan, including internal migration between Russia's regions (people).

\begin{tabular}{|l|c|c|c|c|c|}
\hline & 2008 & 2009 & 2010 & 2011 & 2012 \\
\hline Overall migration growth rate & 10433 & 11211 & 4691 & 11998 & 9786 \\
\hline Including internal migration between regions of Russia & 2651 & 2220 & 3045 & 3429 & 2853 \\
\hline
\end{tabular}

It is notable that the total flow of migrants has seriously reduced, and the number of entrants from other regions of Russia significantly increased compared with the previous period. In general, reducing the number of international migrants was due to the effects of the global economic crisis in 2008 and the change in migration policy. Uzbekistan and Tajikistan are unquestionable leaders in international migration exchanges with the Republic of Tatarstan. These two countries represented a third of all migrants (It is from these two countries, labor migration is more than a third of the total migration growth) (Table 2). Not only the employment opportunity is contributing to migration. Many researchers have observed interethnic tolerance, which is a historical advantage of the Republic of Tatarstan. For centuries here live peacefully 2 main ethnic groups- Tatars and Russians [7].

Table 2. Main (leading) countries in migration stream exchange with the Republic of Tatarstan(people).

\begin{tabular}{|c|l|c|c|c|c|c|}
\hline & Countries & 2008 & 2009 & 2010 & 2011 & 2012 \\
\hline 1 & Uzbekistan & 3498 & 3823 & 509 & 3069 & 3002 \\
\hline 2 & Tajikistan & 1239 & 1660 & 307 & 1646 & 1131 \\
\hline 3 & Azerbaijan & 806 & 834 & 137 & 708 & 582 \\
\hline 4 & Kyrgyzstan & 522 & 547 & 459 & 1297 & 575 \\
\hline 5 & Kazakhstan & 382 & 401 & 184 & 338 & 501 \\
\hline 6 & Armenia & 508 & 523 & 87 & 401 & 374 \\
\hline 7 & Ukraine & 355 & 493 & -12 & 365 & 272 \\
\hline 8 & Turkmenistan & 157 & 139 & 33 & 158 & 105 \\
\hline 9 & Moldova & 104 & 120 & 20 & 114 & 92 \\
\hline 10 & Georgia & 71 & 122 & 27 & 128 & 69 \\
\hline & Other countries & 140 & 329 & -105 & 345 & 230 \\
\hline
\end{tabular}

\section{Conclusion}

The analysis shows that in recent years there have been positive trends in demographics of Republic of Tatarstan. They are: rise in the birth rate and relative stability in the mortality rate. Besides increasing number of marriages and decreasing divorce rate were observed in 2012 year (number of marriages increased and divorce rate have decreased). These trends are likely associated with a relatively stable economic situation in comparison with the 90-ies of XX century, and may serve as a positive indicator of an active demographic policy at both the federal and regional level which based on the idea of stimulating fertility.

Migration growth is important for the republic. Leading countries in migration stream exchange with the Republic of Tatarstan are Uzbekistan and Tajikistan. Labor migration is the main type of migration for representatives of these countries and migrant workers are employed in low-skilled jobs as a rule.

The most important socio-demographic policy goals for the near future should be considered:

- $\quad$ strengthening positive trends in fertility;

- municipal authorities should take into account the current situation, and create opportunities for families to educate and bring up their children - opening of kindergarten (this task is carry out in the Tatarstan), supporting the existing and opening new educational, training and care centers (including sport, art, music etc.) both for preschool children and teenagers;

- increase in life expectancy;

- strengthening family values in society;

- regulation of migration flows for the vacant positions of employment 


\section{References}

Wilson T. (2013) Quantifying the uncertainty of regional demographic forecasts. Applied Geography 42: 108-115

Alho J.M. (2014) Forecasting demographic forecasts. International Institute of Forecasters. http://dx.doi.org/10.1016/.ijforecast. 2014.02.005

Keyfitz, N. (1981). The limits of population forecasting. Population and Development Review, 7(4), 579-593.

Kramin, T. V., Ismagilova, G. N., \& Kramin, M. V. (2014). Assessment of Effect of Large Investment Projects on Development of Investment Potential of Regions of Russia as Exemplified by Universiade 2013 in Kazan1. Mediterranean Journal of Social Sciences, 5(18), 255.

Hyndman R.J., Booth H. (2008) Stochastic population forecasts using functional data models for mortality, fertility and migration. International Journal of Forecasting 24: 323-342 doi:10.1016/j.jiforecast.2008.02.009

Yija"la" A., Jasinskaja-Lahti I., (2010) Pre-migration acculturation attitudes among potential ethnic migrants from Russia to Finland. International Journal of Intercultural Relations 34: 326-339

Biktimirov N.M., Gaisin R.I., Gaisin I.T.(2014) The use of new methodologies for demographic investigations in national-territorial subdivisions of Russia. Life Sci J;11(8s):194-197.

Kramin, T. V., Safiullin, L. N., \& Timiryasova, A. V. (2014). Defining Priorities of Management of Investment Attractiveness of the Region and their Consideration in the Framework of Implementing Large Sports Events1. Mediterranean Journal of Social Sciences, 5(18), 275.

Gaisin, I.T., Biktimirov N.M., (2014). Migration Processes in the Republic of Tatarstan in the Second Half of the 20th and in the Early of 21st Centuries: Ethnic and Social Aspects. Middle - East Journal of Scientific Research, 20(12): 1761-1766, www.idosi.org/mejsr/mejsr20(12)14/12.pdf.

Yanyan Liu, Futoshi YamauchiPopulation density, migration, and the returns to human capital and land: Insights from Indonesia. Food Policy 48 (2014) 182-193 http://dx.doi.org/10.1016/j.foodpol.2014.05.003

Anderson B. (2014) Nations, migration and domestic labor: The case of the UK. Women's Studies International Forum 46 5-12 http://dx.doi.org/10.1016/j.wsif.2014.01.005

Kramin, M. V., Safiullin, L. N., Kramin, T. V., \& Timiryasova, A. V. (2014). Drivers of economic growth and investment attractiveness of Russian regions. Life Science Journal, 11(6s).

Kulu H., Washbrook T. Residential context, migration and fertility in a modern urban society Advances in Life Course Research 21 (2014) 168-182 http://dx.doi.org/10.1016/j.alcr.2014.01.001

Prayitno G., Matsushima K., Jeong H., Kobayashi K. (2014) Social Capital and Migration in Rural Area Development. Procedia Environmental Sciences 20 (2014) $543-552$.

Ismagilova G.N., Safiullin L.N., Bagautdinova N.G. Tourism development in region based on historical heritage. Life Science Journal 2014; 11(6s):363-367.

Safiullin L.N., Novenkova A.Z., Safiullin N.Z., Ismagilova G.N. Prospects of small business in Tatarstan. Life Science Journal 2014; 11(6s): $396-399$.

Komarova, V.N., Zjablova, O.V., Denmukhametov, R.R. An infrastructure factor in regional competitiveness. Mediterranean Journal of Social Sciences, 5 (18 SPEC. ISSUE), pp. 355-360.

Denmukhametov, R.R., Zjablova, O.V. Geodemographic situation in the Republic of Tatarstan. World Applied Sciences Journal, 30 (11), pp. 1684-168. 